\title{
RPA3 wt Allele
}

National Cancer Institute

\section{Source}

National Cancer Institute. RPA3 wt Allele. NCI Thesaurus. Code C116638.

Human RPA3 wild-type allele is located in the vicinity of $7 p 21.3$ and is approximately $82 \mathrm{~kb}$ in length. This allele, which encodes replication protein A 14 kDa protein, is involved in DNA repair, replication and recombination. 